\title{
HUMAN UMBILICAL CORD STEM CELLS - THE DISCOVERY, HISTORY AND POSSIBLE APPLICATION
}

\author{
Katarzyna Stefańska ${ }^{1}$, Rut Bryl ${ }^{1}$, Greg Hutchings ${ }^{2,3}$, Jamil A. Shibli ${ }^{4}$, Marta Dyszkiewicz-Konwińska ${ }^{2,5}$
}

\begin{abstract}
Stem cells are now one of the most extensively studied fields in experimental medicine. Although embryonic stem cells (ESCs) have the capability to differentiate into lineages derived from all three primary germ layers, their use remains ethically controversial. Mesenchymal stromal cells' (MSCs) utilization is not burdened with such concerns. MSCs were primarily characterized as fibroblastic cells from bone marrow stroma, with the ability to adhere to plastic and form clonogenic colonies (CFU-Fs - colony-forming unit-fibroblasts). Subsequent studies led to their isolation from various other adult or perinatal tissues, including the umbilical cord. Although in most cases MSCs are obtained from umbilical cords' stroma (Wharton's jelly), it has been demonstrated that both cord's lining and endothelial layer of umbilical vein possess the cells that fulfill the minimal criteria for MSCs published in 2006 by the International Society for Cellular Therapy. Since the initial discovery, a number of pre-clinical and clinical studies were conducted with the use of MSCs derived from umbilical cords, targeting diseases such as cancer or autoimmune diseases. Moreover, their secretome may be even more beneficial, providing an opportunity to create cell-free therapies.
\end{abstract}

Running title: The history of human umbilical cord stem cells

Keywords: umbilical cord, mesenchymal stem cells, mesenchymal stromal cells, discovery

\footnotetext{
${ }^{1}$ Department of Histology and Embryology, Poznan University of Medical Sciences, Poznan, Poland

${ }^{2}$ Department of Anatomy, Poznan University of Medical Sciences, Poznan, Poland

${ }^{3}$ The School of Medicine, Medical Sciences and Nutrition, Aberdeen University, Aberdeen, United Kingdom

${ }^{4}$ Department of Periodontology and Oral Implantology, Dental Research Division, University of Guarulhos, Guarulhos, SP, Brazil

${ }^{5}$ Department of Biomaterials and Experimental Dentistry, Poznan University of Medical Sciences, Poznan, Poland

* Correspondence: mdyszkiewicz@ump.edu.pl

Full list of author information is available at the end of article
} 


\section{Introduction}

Stem cells are currently one of the most studied subjects in modern experimental medicine, especially in regard to regenerative and cellular therapies. This is due to their unique characteristics, such as self-renewal, differentiation capacity and robust immunomodulatory properties. Several types of stem cells may be distinguished in the human organism. Embryonic stem cells (ESCs) are derived from the inner cell mass of the blastocyst and have the capability to differentiate into cell lineages of all three primary germ layers, and are therefore considered pluripotent [1]. In the adult organism there are two main categories of stem cells - hematopoietic and mesenchymal - the latter being the main focus of this review.

Mesenchymal stem cells (MSCs) seem to possess certain features that make them especially attractive tool in clinical environment. They are able to home to the injured tissues [2], modulate their environment through the secretion of various factors such as cytokines or growth factors [3] and influence the immunologic system via multiple pathways [4]. Their use is non-controversial as compared to ESCs, and they are relatively easily obtainable. Those derived from bone marrow have been the gold standard for MSCs for decades, however their extraction involves a painful procedure and the cell number decreases with the age of the patient, as a result of transformation of red to yellow marrow [5]. It was also suggested that younger tissues, such as perinatal or fetal tissues, would have a greater capacity to proliferate in vitro, before becoming senescent [5]. Therefore, other sources of human MSCs have been found and extensively studied, including the umbilical cord.

\section{Mesenchymal stem cells' (MSCs) characteristics}

The first notion of mesenchymal stem cells was in 1960-1970, when Friedenstein and colleagues isolated a population from bone marrow cells that were significantly different from hematopoietic stem cells usually found in this tissue. These cells were plastic-adherent during in vitro culture and formed colonies designated colony-forming unit-fibroblasts (CFU-Fs), given their fibroblast-like shape [6]. These cells were assumed to be derived from the bone marrow stroma and were called 'bone marrow osteogenic stem cells', considering their differentiation potential towards the bone [7]. Their ability to differentiate into osteoblasts, chondroblasts and adipocytes was confirmed and demonstrated in vitro by Pittenger et al. in 1999 [8]. The term 'mesenchymal stem cells' was not used until 1991, when Caplan proposed it [9]. However, there have been some controversies such as whether these cells are indeed stem cells or even if they are of mesenchymal origin [10]. Therefore, in 2005, the International Society for Cellular Therapy proposed another name: 'multipotent mesenchymal stromal cells' [11].

In order to further unify studies on these cells, the International Society for Cellular Therapy in 2006 listed a set of minimal criteria that MSCs must fulfill [12]. These criteria include: plastic adherence during in vitro culture, differentiation potential towards osteoblasts, chondroblasts and adipocytes, and specific surface antigens expression - MSCs must be positive for CD105 (endoglin), CD73 (5'-nucleotidase) and CD90 (Thy-1), while not expressing CD45 (protein tyrosine phosphatase, receptor type, C), CD34, CD14, CD11b (integrin alpha-M), CD79a (MB-1 membrane glycoprotein), CD19 (B lymphocyte surface antigen B4) or HLA-II (human leukocyte antigen class II) [12].

Although MSCs were primarily characterized as bone marrow stromal cells, subsequent studies led to their isolation from various other tissues, such as dental pulp [13], adipose tissue [14], placenta [15], amniotic fluid [16], human breast milk [17] and many others.

\section{The morphology of human umbilical cord}

Human umbilical cord develops at 26th day of gestation and its primary function is to enable the blood flow between the mother and the fetus, which is vital for proper fetal development. The fully developed umbilical cord is $30-65 \mathrm{~cm}$ long and weighs around $40 \mathrm{~g}$ [18]. It is covered with the cord lining, comprising single or multiple layers of epithelial cells originating from the amnion [19]. In the middle of the umbilical cord three umbilical vessels are located - two arteries and one vein. Importantly, they are devoid of tunica adventitia layer, which distinguishes them from similar vessels [20]. Between the two arteries the median umbilical ligament is located, which is formed after the regression of the allantois [21].

The stroma of umbilical cord comprises all the tissue from under the cord lining to the umbilical vessels and is named 'Wharton's jelly', after an English anatomist Thomas Wharton, who was the first to describe it in 1656 [22]. Wharton's jelly is a gelatinous, mucoid connective tissue composed of amorphous ground substance, containing mostly glycosaminoglycans such as hyaluronic acid or chondroitin sulfate. The main fibrillary components are collagen fibers, while elastic fibers are absent [23]. Wharton's jelly also lacks capillaries or neural tissue [24]. The cell component of this tissue comprises mostly connective tissue cells - fibroblasts, which in this case have properties of both fibroblasts and muscle cells, are therefore considered 'myofibroblasts' at various degrees of differentiation $[23,25]$. 


\section{Umbilical cord stem cells}

The presence of hematopoietic stem and progenitor cells in umbilical cord blood was demonstrated as early as 1974 by Knudtzon et al. [26]. The first umbilical cord blood transplantation was performed in 1988, in a patient with Fanconi anemia, who received cells from HLA identical healthy sibling [27]. The result of this treatment was a complete remission for more than 20 years and no graft-versus-host-disease occurred [28]. Further cord blood transplants, including those with unrelated, mismatched recipients, led to the establishment of Netcord in 1998 - a cord blood allocation network [29].

The umbilical cord tissue itself was regarded as medical waste until 1991, when McElreavy et al. isolated fibroblast-like cells from this tissue's stroma [30]. As previously mentioned, subsequent studies led to the assumption that these cells were indeed myofibroblasts [25]. Their further characterization revealed that they express adhesion molecules (CD44, CD105), integrin markers (CD29, CD51) and MSCs markers such as SH2 or SH3, while not expressing hematopoietic antigens (CD34, CD45) [31]. Markers of pluripotency, such as Oct-4, SSEA-1 and SSEA-4 were also revealed to be expressed in these cells [32], and their differentiation towards osteoblasts, chondroblasts and adipocytes was demonstrated [33], indicating that they could be classified as MSCs. Importantly, the differentiation capability of Wharton's jelly-derived MSCs is much greater, since they were induced to form cardiomyocytes [31], muscle cells [34], neurons [35], hepatocyte-like cells [36] or pancreatic islet-like cell clusters [37].

Since the first isolation of MSCs from Wharton's jelly, a number of authors obtained cells with MSCs properties from other compartments of umbilical cord as well. In 2003 Covas et al. isolated cells from the endothelial and subendothelial layer of umbilical vein [20]. These cells exhibited differentiation potential and specific marker expression consistent with MSCs criteria; they were positive for CD29, CD13, CD44, CD49e, CD54, CD90 and HLA-I, and negative for CD45, CD14, glycophorin A or HLA-DR [20]. Additionally, their differentiation towards cardiomyocytes was performed in vitro as well [38].

MSCs may be obtained from another compartment of human umbilical cord - the cord lining. Gonzalez et al. isolated MSCs-like cells from fragments of cord lining of both pre- and postnatal umbilical cords [39]. Their characterization revealed that these cells were positive for CD 44, CD73, CD90, CD105, CD106, STRO-1 or SSEA-4, while being negative for CD19, CD34, CD45, CD117, CD133 and HLA-DR [39]. The expression of embryonic stem cell markers, such as Oct-4, Nanog, Rex1 or Sox2 was also demonstrated [40]. Moreover, apart from being able to differentiate into osteoblasts, chondroblasts and adipocytes, their neurogenic and cardiac potential was demonstrated as well, indicating that they could be utilized in cellular therapies [39].

\section{The possible application of umbilical cord stem cells}

Since their initial discovery and characterization, umbilical cord stem cells have been used in multiple cellular therapies and clinical trials, targeting immunologic/inflammatory-related disorders, cancer, tissue regeneration or neurodegenerative diseases. There are currently 486 clinical trials utilizing umbilical cord stem cells registered on the website ClinicalTrials.gov, with 118 trials being already completed, including cells derived from both umbilical blood and umbilical tissue.

In the most recently published study, the umbilical cord mesenchymal stem cells (UC-MSCs) were used as a therapy for rheumatoid arthritis patients [41]. 64 patients received intravenously $40 \mathrm{ml}$ of UCMSCs suspension $\left(2 \times 10^{7}\right.$ cells $\left./ 20 \mathrm{ml}\right)$ along with disease-modifying anti-rheumatic drugs (DMARDs) and the results were assessed after 1 year and 3 years. After 3 years post treatment the effects of the therapy with UC-MSCs combined with DMARDs maintained, and included: reduced levels of RF, CRP, ESR and anti-CCP, lower HAQ and DAS28 scores and general alleviation of rheumatoid arthritis symptoms. It was suggested that UC-MSCs regulated patients' autoimmune tolerance, resulting in quality of life improvement [41]. With regards to arthritic disease treatments, it was also suggested that utilizing the secretome of these cells would be beneficial. Miranda et al. cultured UC-MSCs in 3D and injected the culture medium into Wistar rats with adjuvant-induced arthritis [42]. Such treatment resulted in amelioration of arthritis' manifestations to a greater deal than using culture medium from monolayer culture or even UC-MSCs themselves. It was hypothesized to be due to the fact that 3D culture medium was abundant in anti-inflammatory cytokines, such as IL-10 and LIF [42].

One of the most recent trials concerning UC-MSCs utilization in tissue regeneration regarded MSCs derived from Wharton's jelly in chronic skin ulcer treatment [43]. The authors seeded the stem cells on the acellular amniotic membrane and covered with it the wounds of five patients with chronic diabetic wounds for 9 days, with a 1-month follow-up. As a result, the wound healing time and the size of the wound were significantly decreased and some patients reported a decline in pain, probably due to anti-inflammatory, immunomodulatory and angiogenic properties of MSCs [43].

Spinal cord injury could be a potential target of UC-MSCs therapy as well. Recently, Xiao et al. seeded UC-MSCs on collagen scaffold (NeuroRegen scaffold) in order to decrease the diffusion of cells from the injury site [44]. Next, they transplanted these scaffolds into transected spinal cord gap to bridge the defect in patients with spinal cord injury, which resulted in regaining the supraspinal control of movements below the injury [44]. Similarly, Deng et al. administered UC-MSCs loaded onto collagen scaf- 
fold to the injury site in patients with spinal cord injury, and observed bowel and urinary functions recovery, formation of new nerve fiber connections and recovery of electrophysiological activity [45].

Some authors aimed to treat liver diseases with UC-MSCs. One of the first clinical trials to treat liver cirrhosis was conducted as early as 2011 , when 30 patients received intravenously $0.5 \times 10^{6}$ cells $/ \mathrm{kg}$ of body weight three times, at every four weeks [46]. No adverse events were reported, moreover the liver function was improved and ascites volume decreased [46]. More recently, the other group aimed to treat another liver-associated condition with UCMSCs - ischemic-type biliary lesions following liver transplantation. They injected intravenously six doses of UC-MSCs (about 1 x $10^{6}$ cells $/ \mathrm{kg}$ of body weight) to twelve ischemic-type biliary lesions patients and observed a decrease in bilirubin, $\gamma$-glutamyl transferase and alkaline phosphatase levels at week 20 and 48 [47]. In addition, such therapy significantly reduced the need to perform interventional therapies, and graft survival rate was higher compared to the control [47].

It was hypothesized that UC-MSCs may exert anti-tumorigenic properties as well. Therefore, Gauthaman et al. treated breast adenocarcinoma, ovarian carcinoma and osteosarcoma cell lines with either UC-MSCs culture medium or their cell lysate [48]. In case of all three cell lines cell shrinkage was observed and apoptosis- and autophagy-related genes were upregulated, indicative of tumor inhibitory properties of UC-MSCs [48]. Another approach in cancer therapy is to treat UC-MSCs as vehicles for targeted biologic agent delivery, as did Matsuzuka and colleagues in their study [49]. They transfected human UC-MSCs with IFN- $\beta$ gene and cocultured it with human bronchoalveolar carcinoma cell lines, which led to cancer growth inhibition. After the systemic transplantation of transfected UC-MSCs into SCID mice, the growth of bronchioalveolar carcinoma xenografts was attenuated [49].

\section{Conclusions}

Umbilical cord stem cells comprise cells obtained from the cord lining, Wharton's jelly or the umbilical vein's endothelium. Importantly, all these types of cells exhibit specific surface antigens' expression pattern and are capable of at least trilineage differentiation, and therefore fulfill minimal criteria to be considered MSCs. Although MSCs were isolated from the umbilical cord for the first time nearly 30 years ago, the amount of studies and clinical trials with their use is impressive. Their accessibility and ease of cultivation make them attractive tool not only for cellular therapies, but for tissue engineering as well. They were proven to improve condition of patients with such diseases as spinal cord injury, liver cirrhosis, chronic skin ulcers or rheumatoid arthritis. The fact that they are able to exert many therapeutic effects in a paracrine manner seems to be especially promising, as it creates the opportunity to design cell-free therapies, not burdened with the risk of cellular graft complications.

\section{Ethical approval}

The conducted research is not related to either human or animal use.

\section{Acknowledgments}

This publication and its results are an outcome of a cooperation between Poznan University of Medical Sciences (Poznań, Poland) and Polish Ministry of Science and Higher Education, with Cellivia 3 SA (Poznań, Poland), as a part of the "Professional PhD" program.

\section{Corresponding author}

Marta Dyszkiewicz-Konwińska, Department of Biomaterials and Experimental Dentistry, Poznań University of Medical Sciences, 70 Bukowska St., 60-812 Poznań, Poland and Department of Anatomy, Poznań University of Medical Sciences, 6 Święcickiego St., 60-781 Poznań, Poland, Tel./Fax: +48 61 8546565, e-mail: mdyszkiewicz@ump.edu.pl.

\section{Conflicts of interest statement}

The authors declare they have no conflict of interest.

\section{References}

1. Doğan A. Embryonic stem cells in development and regenerative medicine. Adv. Exp. Med. Biol. 2018;1-15; DOI:10.1007/5584_2018_175.

2. Yagi H, Soto-Gutierrez A, Parekkadan B, Kitagawa Y, Tompkins RG, Kobayashi N, Yarmush ML. Mesenchymal stem cells: Mechanisms of immunomodulation and homing. Cell Transplant. 2010; DOI:10.3727/096368910X508762.

3. Kupcova Skalnikova H. Proteomic techniques for characterisation of mesenchymal stem cell secretome. Biochimie. 2013; DOI:10.1016/j. biochi.2013.07.015.

4. Shi Y, Wang Y, Li Q, Liu K, Hou J, Shao C, Wang Y. Immunoregulatory mechanisms of mesenchymal stem and stromal cells in inflammatory diseases. Nat Rev Nephrol. 2018; DOI:10.1038/s41581-018-0023-5.

5. Weiss ML, Troyer DL. Stem cells in the umbilical cord. Stem Cell Rev. 2006;2:155-62; DOI:10.1007/s12015-006-0022-y.

6. Friedenstein AJ, Chailakhjan RK, Lalykina KS. The development of fibroblast colonies in monolayer cultures of guinea-pig bone marrow and spleen cells. Cell Prolif. 1970;3:393-403; D0I:10.1111/j.1365-2184.1970.tb00347.x.

7. Friedenstein AJ, Chailakhyan RK, Gerasimov U V. Bone marrow osteogenic stem cells: in vitro cultivation and transplantation in diffusion chambers. Cell Prolif. 1987; DOI:10.1111/j.1365-2184.1987.tb01309.x.

8. Pittenger MF, Mackay AM, Beck SC, Jaiswal RK, Douglas R, Mosca JD, Moorman MA, Simonetti DW, Craig S, Marshak DR. Multilineage potential of adult human mesenchymal stem cells. Science (80- ). 1999; DOI:10.1126/science.284.5411.143.

9. Caplan AI. Mesenchymal stem cells. J Orthop Res. 1991; DOI:10.1002/ jor.1100090504.

10. Bianco P, Robey PG, Simmons PJ. Mesenchymal stem cells: revisiting history, concepts, and assays. Cell Stem Cell. 2008; DOI:10.1016/j. stem.2008.03.002.

11. Horwitz EM, Le Blanc K, Dominici M, Mueller I, Slaper-Cortenbach I, Marini FC, Deans RJ, Krause DS, Keating A. Clarification of the nomenclature for MSC: The International Society for Cellular Therapy position statement. Cytotherapy. 2005; DOI:10.1080/14653240500319234.

12. Dominici M, Le Blanc K, Mueller I, Slaper-Cortenbach I, Marini FC, Krause DS, Deans RJ, Keating A, Prockop DJ, Horwitz EM. Minimal criteria for defining multipotent mesenchymal stromal cells. The International Society for Cellular Therapy position statement. Cytotherapy. 2006;8:3157; DOI:10.1080/14653240600855905.

13. Gronthos S, Mankani M, Brahim J, Robey PG, Shi S. Postnatal human dental pulp stem cells (DPSCs) in vitro and in vivo. Proc Natl Acad Sci U S A. 2000; DOI:10.1073/pnas.240309797.

14. Katz AJ, Tholpady A, Tholpady SS, Shang H, Ogle RC. Cell surface and transcriptional characterization of human adipose-derived adherent stromal (hADAS) cells. Stem Cells. 2005; DOI:10.1634/stemcells.2004-0021.

15. in 't Anker PS, Scherjon SA, Kleijburg-van der Keur C, de Groot-Swings GMJS, Claas FHJ, Fibbe WE, Kanhai HHH. Isolation of mesenchymal stem cells of fetal or maternal origin from human placenta. Stem Cells. 2004; DOI:10.1634/stemcells.2004-0058. 
16. In 't Anker PS, Scherjon SA, Kleijburg-van der Keur C, Noort WA, Claas FHJ, Willemze R, Fibbe WE, Kanhai HHH. Amniotic fluid as a novel source of mesenchymal stem cells for therapeutic transplantation. Blood. 2003;102:1548-9; DOI:10.1182/blood-2003-04-1291.

17. Patki S, Kadam S, Chandra V, Bhonde R. Human breast milk is a rich source of multipotent mesenchymal stem cells. Hum Cell. 2010 DOI:10.1111/j.1749-0774.2010.00083.x.

18. Arutyunyan I, Elchaninov A, Makarov A, Fatkhudinov T. Umbilical cord as prospective source for mesenchymal stem cell-based therapy. Stem Cells Int. 2016;2016:6901286; DOI:10.1155/2016/6901286.

19. Can A, Karahuseyinoglu S. Concise review: Human umbilical cord stroma with regard to the source of fetus-derived stem cells. Stem Cells. 2007;25:2886-95; DOI:10.1634/stemcells.2007-0417.

20. Covas DT, Siufi JLC, Silva ARL, Orellana MD. Isolation and culture of umbilical vein mesenchymal stem cells. Brazilian J Med Biol Res. 2003;36:1179-83; DOI:10.1590/S0100-879X2003000900006.

21. Spurway J, Logan P, Pak S. The development, structure and blood flow within the umbilical cord with particular reference to the venous system. Australas J Ultrasound Med. 2012;15:97-102; D0I:10.1002/j.2205-0140.2012.tb00013.x

22. Lyons FG, Mattei TA. Sources, identification, and clinical implications of heterogeneity in human umbilical cord stem cells. Adv. Exp. Med. Biol. 2019;1169:243-56; DOI:10.1007/978-3-030-24108-7_13.

23. Nanaev AK, Kohnen G, Milovanov AP, Domogatsky SP, Kaufmann P. Stromal differentiation and architecture of the human umbilical cord. Placenta. 1997;18:53-64; DOI:10.1016/S0143-4004(97)90071-0

24. Davies JE, Walker JT, Keating A. Concise review: Wharton's jelly: the rich, but enigmatic, source of mesenchymal stromal cells. Stem Cells Trans Med. 2017;6:1620-30; DOI:10.1002/sctm.16-0492

25. Takechi K, Kuwabara Y, Mizuno M. Ultrastructural and immunohistochemical studies of Wharton's jelly umbilical cord cells. Placenta. 1993;14:235-45; DOI:10.1016/S0143-4004(05)80264-4.

26. Knudtzon S. In vitro growth of granulocytic colonies from circulating cells in human cord blood. Blood. 1974; DOI:10.1182/blood. V43.3.357.357.

27. Gluckman E, Broxmeyer HE, Auerbach AD, Friedman HS, Douglas GW, Devergie A, Esperou H, Thierry D, Socie G, Lehn P, Cooper S, English D, Kurtzberg J, Bard J, Boyse EA. Hematopoietic reconstitution in a patient with Fanconi's anemia by means of umbilical-cord blood from an HLA-identical sibling. N Engl J Med. 1989; DOI:10.1056/NEJM198910263211707.

28. Munoz J, Shah N, Rezvani K, Hosing C, Bollard CM, Oran B, Olson A, Po pat U, Molldrem J, McNiece IK, Shpall EJ. Concise review: umbilical cord blood transplantation: past, present, and future. Stem Cells Transl Med. 2014; DOI:10.5966/sctm.2014-0151.

29. Hakenberg P, Kögler G, Wernet P. NETCORD: A cord blood allocation network. Bone Marrow Transplant., 1998.

30. McElreavey KD, Irvine AI, Ennis KT, McLean WHI. Isolation, culture and characterisation of fibroblast-like cells derived from the Wharton's jelly portion of human umbilical cord. Biochem. Soc. Trans. 1991;19, DOI:10.1042/bst019029s

31. Wang HS, Hung SC, Peng ST, Huang CC, Wei HM, Guo YJ, Fu YS, La MC, Chen CC. Mesenchymal stem cells in the Wharton's jelly of the human umbilical cord. Stem Cells. 2004;22:1330-7; DOI:10.1634/ stemcells.2004-0013.

32. Fong CY, Richards M, Manasi N, Biswas A, Bongso A. Comparative growth behaviour and characterization of stem cells from human Wharton's jelly. Reprod Biomed Online. 2007;15:708-18; DOI:10.1016/ S1472-6483(10)60539-1.

33. Karahuseyinoglu S, Cinar O, Kilic E, Kara F, Akay GG, Demiralp DÖ, Tukun A, Uckan D, Can A. Biology of stem cells in human umbilical cord stroma: in situ and in vitro surveys. Stem Cells. 2007;25:319-31; DOI:10.1634/ stemcells.2006-0286.

34. Conconi MT, Burra P, Di Liddo R, Calore C, Turetta M, Bellini S, Bo P, Nussdorfer GG, Parnigotto PP. CD105(+) cells from Wharton's jelly show in vitro and in vivo myogenic differentiative potential. Int J Mol Med. 2006;18:1089-96; DOI:10.3892/ijmm.18.6.1089.

35. Mitchell KE, Weiss ML, Mitchell BM, Martin P, Davis D, Morales L, Helwig B, Beerenstrauch M, Abou-Easa K, Hildreth T, Troyer D. Matrix cells from Wharton's jelly form neurons and glia. Stem Cells. 2003;21:50-60 DOI:10.1634/stemcells.21-1-50.

36. Bharti D, Shivakumar SB, Park JK, Ullah I, Subbarao RB, Park JS, Lee SL, Park BW, Rho GJ. Comparative analysis of human Wharton's jelly mesenchymal stem cells derived from different parts of the same umbilical cord. Cell Tissue Res. 2018;372:51-65; DOI:10.1007/ s00441-017-2699-4.

37. Chao KC, Chao KF, Fu YS, Liu SH. Islet-like clusters derived from mesenchymal stem cells in Wharton's jelly of the human umbilical cord for transplantation to control type 1 diabetes. PLoS One. 2008;3; DOI:10.1371/journal.pone.0001451.

38. Kadivar M, Khatami S, Mortazavi Y, Shokrgozar MA, Taghikhani M, Soleimani M. In vitro cardiomyogenic potential of human umbilical vein-derived mesenchymal stem cells. Biochem Biophys Res Commun. 2006;340:639-47; DOI:10.1016/j.bbrc.2005.12.047.

39. Gonzalez R, Griparic L, Umana M, Burgee K, Vargas V, Nasrallah R, Silva F, Patel A. An efficient approach to isolation and characterization of preand postnatal umbilical cord lining stem cells for clinical applications Cell Transplant. 2010;19:1439-49; DOI:10.3727/096368910X514260.

40. Reza HM, Ng BY, Phan TT, Tan DTH, Beuerman RW, Ang LPK. Characterization of a novel umbilical cord lining cell with CD227 positivity and unique pattern of P63 expression and function. Stem Cell Rev Reports. 2011;7:624-38; DOI:10.1007/s12015-010-9214-6.

41. Wang L, Huang S, Li S, Li M, Shi J, Bai W, Wang Q Zheng L, Liu Y. Efficacy and safety of umbilical cord mesenchymal stem cell therapy for rheumatoid arthritis patients: A prospective phase I/II study. Drug Des Devel Ther. 2019; DOI:10.2147/DDDT.S225613.

42. Miranda JP, Camões SP, Gaspar MM, Rodrigues JS, Carvalheiro M, Bárcia RN, Cruz P, Cruz H, Simões S, Santos JM. The secretome derived from 3D-cultured umbilical cord tissue MSCS counteracts manifestations typifying rheumatoid arthritis. Front Immunol. 2019; DOI:10.3389/ fimmu.2019.00018.

43. Hashemi SS, Mohammadi AA, Kabiri H, Hashempoor MR, Mahmoodi M, Amini M, Mehrabani D. The healing effect of Wharton's jelly stem cells seeded on biological scaffold in chronic skin ulcers: A randomized clinical trial. J Cosmet Dermatol. 2019; DOI:10.1111/jocd.12931.

44. Xiao Z, Tang F, Zhao Y, Han G, Yin N, Li X, Chen B, Han S, Jiang X, Yun C, Zhao C, Cheng S, Zhang S, Dai J. Significant improvement of acute complete spinal cord injury patients diagnosed by a combined criteria implanted with NeuroRegen scaffolds and mesenchymal stem cells. Cell Transplant. 2018; DOI:10.1177/0963689718766279.

45. Deng WS, Ma K, Liang B, Liu XY, Xu HY, Zhang J, Shi HY, Sun HT, Chen XY, Zhang S. Collagen scaffold combined with human umbilical cord-mesenchymal stem cells transplantation for acute complete spinal cord injury. Neural Regen Res. 2020; DOI:10.4103/1673-5374.276340.

46. Zhang Z, Lin H, Shi M, Xu R, Fu J, Lv J, Chen L, Lv S, Li Y, Yu S, Geng H, Jin L, Lau GKK, Wang FS. Human umbilical cord mesenchymal stem cells improve liver function and ascites in decompensated liver cirrhosis patients. Gastroenterol Hepatol. 2012; DOI:10.1111/j.1440-1746.2011.07024.x.

47. Zhang YC, Liu W, Fu BS, Wang GY, Li HB, Yi HM, Jiang N, Wang G, Zhang J, Yi SH, Li H, Zhang Q Yang Y, Chen GH. Therapeutic potentials of umbilica cord-derived mesenchymal stromal cells for ischemic-type biliary lesions following liver transplantation. Cytotherapy. 2017; DOI:10.1016/j. jcyt.2016.11.005.

48. Gauthaman K, Yee FC, Cheyyatraivendran S, Biswas A, Choolani M, Bongso A. Human umbilical cord Wharton's jelly stem cell (hWJSC) extracts inhibit cancer cell growth in vitro. J Cell Biochem. 2012; DOI:10.1002/ jcb.24073.

49. Matsuzuka T, Rachakatla RS, Doi C, Maurya DK, Ohta N, Kawabata A, Pyle MM, Pickel L, Reischman J, Marini F, Troyer D, Tamura M. Human umbilical cord matrix-derived stem cells expressing interferon- $\beta$ gene significantly attenuate bronchioloalveolar carcinoma xenografts in SCID mice Lung Cancer. 2010;70:28-36; DOI:10.1016/j.lungcan.2010.01.003. 